\title{
Evolution and the Media
}

\author{
Carl Zimmer
}

Published online: 17 March 2010

(C) Springer Science+Business Media, LLC 2010

\begin{abstract}
Journalists have been writing about evolution since Darwin first published the Origin of Species. Today, news about evolution comes in a dizzying diversity of venues. In this paper, I survey this diversity, observing its strengths and weaknesses for helping students learn about evolution.
\end{abstract}

Keywords Evolution · Media · Internet - Education ·

Paleontology $\cdot$ Journalism $\cdot$ Blogs

\section{"A Radical Reconstruction"}

Evolution has been news from the start. On March 28, 1860, The New York Times ran a massive article on a newly published book called On the Origin of Species (Anonymous 1860). The article explained how the dominant explanation for life's staggering diversity was the independent creation of every species on Earth. "Meanwhile," the anonymous author wrote, "Mr. DARWIN, as the fruit of a quarter of a century of patient observation and experiment, throws out, in a book whose title has by this time become familiar to the reading public, a series of arguments and inferences so revolutionary as, if established, to necessitate a radical reconstruction of the fundamental doctrines of natural history."

Today, some 150 years later, evolutionary biologists are continuing to reconstruct natural history, and journalists are still documenting that reconstruction. Each week brings a flood of new reports about some new insight into evolution.

\section{Zimmer $(\bowtie)$}

Environmental Studies Program, Yale University,

Kroon Hall, 195 Prospect St., Room G04,

New Haven, CT, USA

e-mail: carl@carlzimmer.com
The stories range across the living world, from fossil dinosaurs to the emergence of new strains of viruses to clues embedded in the human genome. The New York Times continues to publish articles about evolution (some by yours truly), as do many other newspapers and magazines. But reports on evolution can also take many new forms that were inconceivable in Darwin's day. They can be television shows, blogs, podcasts, and tweets.

Teachers who want to bring their students up to date on the science evolutionary biology - and to get them excited about this fast-moving field - can select from an overwhelming variety of choices. That's fundamentally a good thing, but it has some downsides. There is a vast amount of information available on the Internet, but much of it is misleading or poorly written. It takes some work to make the best use of news about evolution. And to understand how to make the best use of it requires a little history on how the new media ecology evolved into its current form. (In this essay, I will only examine the coverage of evolutionary biology in the media, not the coverage of creationism or other social controversies that involve evolution. That is a worthy subject, but one that would require a lengthy treatment of its own.)

\section{The Evolution of the Modern Science Writer}

The journalistic coverage of evolution as we know it today began to take shape in the 1970s. Newspapers hired more and more reporters with a specialty in science, and those science writers began paying more attention to evolutionary biology. Boyce Rensberger, a science writer for The New York Times in the 1970s, for example, wrote a string of stories about evolution. A typical Rensberger article appeared on April 12, 1975, entitled "East Africa Fossils 
Suggest That Man Is a Million Years Older Than He Thinks." In a 2,900-word account, Rensberger described the discovery a three-million-year-old fossil of a hitherto unknown species of hominid, Australopithecus afarensis (Rensberger 1975).

Four years later, the Times founded a weekly section dedicated to science - the first science section to ever run in an American newspaper. In the next few years, many other newspapers followed suit. Science magazines enjoyed a boom as well. Old standards like Scientific American were joined by start-ups such as Discover and Omni. All of these new publications gave special attention to evolution.

The reasons for this focus were complex, but one of the most important ones was that there was a lot of news about evolution for reporters to write. A. afarensis was not the only new fossil to capture the public's attention in the 1970s. Dinosaurs, long considered sluggish and slumped, were receiving a makeover. The Yale paleontologist John Ostrom led a new reconstruction of dinosaurs as fast-running, warm-blooded creatures - an upgrade from Godzilla to Jurassic Park.

Geologists were also adding to evolution's cinematic appeal. In the late 1970s Walter Alvarez of the University of California at Berkeley and his colleagues discovered clues that an asteroid smashed into Earth 65 million years ago (Alvarez 2009). It just so happened to have hit right at the end of the Cretaceous Period, a time of mass extinctions that claimed the dinosaurs that Ostrom was rehabilitating. Alvarez made a radical connection between the impact and the mass extinctions. Mass extinctions had long been thought to be stretched across millions years, as sea levels gradually rose or fell. Alvarez and his colleagues offered a vision of sudden disaster. The asteroid impact threw dust and rock high into the atmosphere, causing a global environmental catastrophedarkness for months, acid rain, global warming, and more. In a geological flash, millions of species became extinct.

Alvarez was arguing for a catastrophic mode of evolution. To understand evolution 65 million years ago, we could not simply extrapolate back from the small, incremental changes natural selection produces today from one generation to the next. As a result, some scientists argued, the end-Cretaceous extinctions did not fit into the framework that had dominated evolutionary thought since the mid-1900s, known as the Modern Synthesis.

The Modern Synthesis-an integration of genetics, paleontology, ecology, and other branches of biologyexplained life predominantly as the result of natural selection operating on small differences between individuals over vast periods of time. Challenges to the Modern Synthesis came from studies not just on mass extinctions, but on more tranquil periods of the fossil record. The paleontologists Niles Eldredge and Stephen Jay Gould argued that the fossil record revealed a pattern of stasis and change, a pattern they dubbed punctuated equilibria (Gould
2007). Species remained stable for millions of years, with new species rapidly branching off in just thousands of years. Eldredge and Gould argued that this pattern of evolution allowed selection to take place not just between individuals, but perhaps also between species.

Science writers chronicled not only these challenges to the Modern Synthesis, but also the attempts by other scientists to expand its scope. In 1976, the British zoologist Richard Dawkins, building on the work in the 1960s of George Williams and William Hamilton, published The Selfish Gene (Dawkins 2006). Dawkins argued that evolution was best understood from a gene-centered perspective. The Harvard biologist Edward O. Wilson undertook a similar project, interpreting a vast range of behaviorsfrom the selfless work of sterile worker bees to the bloodshed of human warfare - as strategies for genes to get themselves replicated. In 1975 he unveiled his synthesis in the book Sociobiology (Wilson 1975).

Gould and other scientists attacked these extensions of the Modern Synthesis, arguing that they ascribed far too much power to natural selection. Gould and Harvard geneticist Richard Lewontin condemned sociobiology as promoting "just-so stories"-plausiblesounding tales of adaptation rather than carefully constructed and tested hypotheses (Gould \& Lewontin 1979). Gould and Lewontin argued that evolutionary biologists had to consider many possible explanations beyond natural selection. A behavior of an animal, the shape of a shell, or any other feature of life might be strongly influenced by constraints, for exampleconstraints of history, development, and function.

Science writers were not the only ones who chronicled this debate. Some of the scientists themselves did, too. And some of them proved to be powerful writers, publishing hugely popular books and articles. Wilson won the Pulitzer Prize - twice - for his books. Dawkins's The Selfish Gene proved enormously successful, and has remained in print ever since. Stephen Jay Gould battled against the adaptationism of Dawkins and Wilson every month in the pages of Natural History, as well as in a string of books such as Wonderful Life. Gould passed away in 2002, but today Wilson and Dawkins continue to publish popular books on evolution. Dawkins's latest work, The Greatest Show on Earth, became a best-seller. And Dawkins, Wilson, and Gould have been joined by younger evolutionary biologists turned popular writers, such as Jared Diamond, Steven Pinker, and Frans de Waal.

\section{The Great Transformation}

While these writers published in the traditional venues of books, magazines, and newspapers, a few evolutionary 
biologists and evolution buffs started to experiment with a new medium: the Internet. They set up online discussion groups, such as talk.origins, where they could post comments about new advances in evolutionary biology, as well as the attempts of creationists to block the teaching of evolution in public schools. Later they posted long lists of frequently asked questions about evolution, such as, "If we evolved from monkeys, why are there still monkeys?"

Talk.origins and other evolution discussion groups were founded at a time when few people outside of universities had even heard of the Internet. But as time passed, the number of Internet users grew exponentially. And along the way, systems for posting information online grew more sophisticated. Publishing systems emerged for creating online journals, complete with links, podcasts, photographs, videos, or whatever else a writer wanted to add. A number of veterans of the old evolution discussion groups started up their own journals - known first as web logs, and then, finally, as blogs (Goldstein 2009). Others followed their example, so that today, thanks to the Internet, far more biologists are regularly writing about evolution than ever before.

As blogs have bloomed, the older venues for news on evolution have struggled. A number of science magazines launched in the 1970s and 1980s, such as Omni and Science 80 , eventually folded. Science coverage in newspapers began to get pinched in the 1990s. In 1989, 95 newspapers ran science sections. By 2006 that number had shrunk to just 34 . Those shuttered science sections were the victims of an industry-wide blight. Newspapers were being squeezed for greater profits, even as their readerships declined. They offered their senior staff buyouts in order to reduce labor costs, and a number of the science writers who had been part of the field's first efflorescence left the business.

And then the Internet turned the news business inside out. The online classified web site Craigslist made classified ads in the print editions of newspapers as obsolete as horse-drawn carriages. Companies that might once have taken out full-page ads now poured much of their money into online advertising. They went there because readers had gone to the Internet first. What had once been the purview of die-hard web-lovers like the people at talk. origins became the place where hundreds of millions of people went to learn about many things, including science.

Paradoxically, even as the Internet sucked away much of the revenue of newspapers and magazines, it was driving more readers to them. The New York Times, for example, now has a daily circulation of about one million readers, but receives about 17 million unique visits a month at its web site (http://www.editorandpublisher.com/eandp/news/ article_display.jsp?vnu_content_id $=1004016432$ [Accessed November 7 2009]). The news on their site also radiates outward across the World Wide Web as people comment on it in blogs and forums.

These huge changes in readership are altering the way evolution and other branches of science are reported. The print edition of The New York Times still includes a science section every Tuesday, but it now offers may untraditional kinds of coverage of evolution. It hosts science blogs including "The Wild Side," written by evolutionary biologist Olivia Judson. In 2009 it posted The Origin of Species in an online form, with annotations from some of the world's leading evolutionary biologists. The New York Times now offers podcasts and even short videos about evolution. You almost have to remind yourself that it's still a newspaper.

\section{The Darwinius Affair}

For teachers looking for new ways to engage students in evolution, there's an embarrassment of riches waiting to be explored. Twenty years ago, they had to search slowly through magazines and newspapers for interesting articles, head off to a Xerox machine, and run off a few dozen grainy copies. Now teachers can use Google to zip around the Internet's global library. It takes a few seconds to pull up a list of thousands of articles on Archaeopteryx, or Neanderthals, or balancing selection.

And teachers don't have to limit their searches to articles. Casey Dunn, an evolutionary biologist at Brown University, recently established a blog called Creaturecast about animal evolution. Among their posts, he and his co-bloggers regularly publish innovative videos. One episode explains how single-celled organisms made the evolutionary transition to multicellularity. The whole film is a stop-action animation of purple Play-doh. The Play-doh morphs into cells, which then join together into bodies (http://creaturecast.org/archives/ 410-creaturecast-episode-2 [Accessed November 7 2009]). The video is at once charming and surprisingly enlightening. And, most importantly, it was something no one would have predicted just a couple years ago.

But this new media ecology is also vulnerable to spectacular disasters. In May 2009, scientists unveiled a new fossil of a primate dubbed Darwinius masilae. The unveiling was unique in the annals of paleontology. At the American Museum of Natural History, New York City Mayor Michael Bloomberg and other luminaries gazed at the slab preserving a 47-million-year-old specimen (known as Ida, named after the daughter of one of the paleontologists who described the fossil). Minutes before the press conference commenced, the journal PLOS One electronically published a paper about the fossil (Franzen et al. 2009). Some of the paper's authors, speaking at the press conference, described the fossil as the Holy Grail of paleontology and the lost ark of archeology. 
The scientists were not the only ones to speak that morning. Nancy Dubuc, an executive at the History Channel said that the fossil "promised to change everything that we thought we understood about the origins of human life." (http://www.guardian.co.uk/science/2009/may/19/ida-fossilprimate-media-us [Accessed November 7 2009]). Why was Dubuc there? Because the unveiling of Darwinius was actually a television phenomenon, years in the making.

Television producers had started putting together a bigbudget show about Darwinius even as the scientists were analyzing the fossil and writing up their results. The documentary's main message was also the chief argument in the PLOS One paper: Darwinius belonged to the lineage that led to monkeys, apes, and humans. As a result, it illuminated how our ancestors diverged from more distantly related primates, such as lemurs. As the air date for the documentary approached, the History Channel cranked up a massive publicity machine. A trade book was rushed into print. Ads appeared. YouTube videos spread like viruses. The History Channel set up an elaborate web site called "Revealing the Link." It featured hyperbolic claims from the scientists, such as, "When our results are published, it will be just like an asteroid hitting the Earth." (http://www. revealingthelink.com/ [Accessed November 10 2009]).

As press manipulation, the strategy worked well. Newspapers, magazines, and even television news programs ran stories about Darwinius on the day of its grand unveiling. Few of them would have ever considered covering the discovery of an Eocene primate, it's safe to say, without the elaborate publicity. Unfortunately, most reporters simply relayed hyperbolic quotes from their sources. They also demonstrated some deep misunderstandings about evolution. "Fossil is evolution's missing link," announced The Sun (http://www.thesun.co.uk/sol/homepage/news/ article2437749.ece [Accessed November 10 2009]), falling prey to the common misbelief that paleontologists could ever determine our direct ancestors. (In fact, paleontologists compare related species to determine the pattern by which new traits emerged in different lineages.)

Given the upheavals going on in the media these days, it's not surprising that the press were so swayed by the Darwinius publicity machine. The number of skilled science writers who can report a story like this one with the proper skepticism is dwindling. And all media organizations are racing to be the first to get news online.

Not all science writers took television channels as their authority on human evolution, however. A few veteran journalists tried to get their hands on the paper and show it to other experts on fossil primates to get their opinion on its importance. Seeking outside opinions from experts was all the more important because the Darwinius paper was published in PLOS One. Unlike most other scientific journals, PLOS One does not judge papers based on their scientific importance, but simply on their technical soundness. The journal's editors rely on discussion forums on its web site for an open, post-publication peer review to judge the merits of the paper (http://www.plosone.org/static/guidelines.action [Accessed November 7 2009]).

It's unlikely that many reporters covering the story of Darwinius were familiar with the editorial policies of PLOS One. And the few science writers who tried to get hold of the paper and show it to experts were thwarted. Ann Gibbons, a correspondent for Science, finally got her hands on the paper the weekend before the press conference-but only after signing a non-disclosure agreement with the television company that produced the Darwinius documentary. Gibbons promised not to show the paper to anyone before the press conference (http://blogs.discovermagazine. com/loom/2009/05/21/science-held-hostage/ [Accessed November 7 2009]).

As a result, the first giant wave of articles about Darwinius was based entirely on the press conference and claims from the scientists who had published the PLOS One paper. Eventually, Gibbons and a handful of other science writers were able to publish articles that offered a broad look at Darwinius, rather than the breathless press conference coverage that dominated the news. It turned out that just about all the other experts reporters contacted thought the fossil was impressive, but that the claims of its kinship with humans unjustified. "This hypothesis now lies well outside the scientific mainstream, and the discovery and description of Ida have done little to rehabilitate it," wrote Christopher Beard of the Carnegie Museum of Natural History in the September 2009 issue of American Scientist (http://www.americanscientist.org/bookshelf/pub/ the-weakest-link [Accessed November 7 2009]).

In October 2009, five months after the Darwinius circus had folded its tents and moved on, paleontologists published an important new paper on early primate evolution (Seiffert et al. 2009). They described another early primate fossil, called Afradapis, and then compared its anatomy to Darwinius and a wide range of other primate fossils. Their analysis puts Darwinius on the branch that led to lemurs, not to us. The reaction from the press offered a stark contrast with the pandemonium that greeted Darwinius in May. Very few newspapers and other publications even mentioned the new study. Perhaps if there had been a big-budget documentary on Afradapis, things might have been different.

\section{Teachers: Caveat Emptor}

No teacher should expose students to The Sun's coverage of Darwinius, just as no teacher should expose students to deer ticks. Selecting popular stories about new develop- 
ments in evolutionary biology requires great care. To develop that care, teachers should learn as much as possible about evolution, through textbooks and reliable online sites such as Understanding Evolution (http://evolution.berkeley. edu).They can also tap into the collective wisdom of the blogosphere. Evolution bloggers were quick to ask hard questions about the hype surrounding Darwinius and try to figure out its real significance. They can help teachers distinguish stories about truly important science from stories that are mere fluff.

Teachers must also bear in mind that some sites that claim to offer critiques of news on evolution are actually creationist outlets dedicated to undermining the teaching of evolution. Some of these sites are relatively obvious, such as Creation Safaris (http://creationsafaris.com), while others hide their creationism. A site called "All About Science" (http://www.allaboutscience.org) has a long page entitled "Darwin's Theory of Evolution: A Theory in Crisis." It takes a bit of snooping around to discover that All About Science is produced by an outfit called AllAboutGod.com.

Finally, teachers should resist the rapid-fire allure of the Internet. Rather than leaping on an article the second it hits Google News, they would do well to give the science a little time to develop. After all, the scientific process does not actually run on the news cycle. One revolutionary breakthrough does not follow seconds after another, exploding like cannon fire. It takes time for scientists to gather data and present hypotheses, and for other scientists to look for ways to test those hypotheses. It would have been unwise to use Darwinius in May to help students understand evolution. By October, it became a teachable moment.

Acknowledgments I would like to thank Ann Gibbons, Boyce Rensberger, and Malcolm Ritter for sharing some of their experiences in writing about evolution.

\section{References}

Alvarez WT. Rex and the crater of doom. 2nd ed. Princeton: Princeton University Press; 2009.

Anonymous (1860) "The Origin of Species." The New York Times, March 28, 1860. PDF downloaded from http://www.nytimes.com

Dawkins R. The selfish gene. 30th ed. Oxford: Oxford University Press; 2006.

Franzen JL, Gingerich PD, Habersetzer J, Hurum JH, von Koenigswald W, Smith BH. Complete primate skeleton from the Middle Eocene of Messel in Germany: morphology and paleobiology. PloS One. 2009;4(5):e5723. doi:10.1371/journal.pone.0005723.

Goldstein A. Blogging evolution. Evolution: Education and Outreach. 2009;2:548-59.

Gould SJ. Punctuated equilibrium. 1st ed. Cambridge: Belknap Press of Harvard University Press; 2007.

Gould SJ, Lewontin RC. The spandrels of San Marco and the Panglossian paradigm: a critique of the adaptationist programme. Proceedings of the Royal Society of London Series B. 1979; 205:581-98

Rensberger B (1975). East Africa fossils suggest that man is a million years older than he thinks. New York Times. p 58

Seiffert ER, Perry JMG, Simons EL, Boyer DM. Convergent evolution of anthropoid-like adaptations in Eocene adapiform primates. Nature. 2009;461:7267: (October 22): 1118-1121.

Wilson EO. Sociobiology: the new synthesis. Cambridge: Belknap Press of Harvard University Press; 1975. 